\title{
Equilibrium of sinks and sources of sulphate over Europe: comparison between a six-year simulation and EMEP observations
}

\author{
M. Ménégoz ${ }^{1}$, D. Salas y Melia ${ }^{1}$, M. Legrand ${ }^{2}$, H. Teyssèdre ${ }^{1}$, M. Michou ${ }^{1}$, V.-H. Peuch ${ }^{1}$, M. Martet ${ }^{3}$, B. Josse ${ }^{1}$, and \\ I. Dombrowski-Etchevers ${ }^{4}$ \\ ${ }^{1}$ Météo-France, CNRM-GAME, Toulouse, France \\ ${ }^{2}$ LGGE, Grenoble, France \\ ${ }^{3}$ Météo-France, DP/SERV/ENV, Toulouse, France \\ ${ }^{4}$ Météo-France, CEN, Grenoble, France
}

Received: 5 December 2008 - Published in Atmos. Chem. Phys. Discuss.: 12 February 2009

Revised: 15 June 2009 - Accepted: 30 June 2009 - Published: 14 July 2009

\begin{abstract}
Sulphate distributions were simulated with a global chemistry transport model. A chemical scheme describing the sulphur cycle and the parameterisations of the main sinks for sulphate aerosols were included in the model. A six-year simulation was conducted from the years 2000 to 2005, driven by the ECMWF operational analyses. Emissions come from an inventory representative of the year 2000. This paper focuses on the analysis of the sulphate sinks and sources over Europe for the entire period of simulation. The Sulphate burden shows a marked annual cycle, which is the result of the annual variations of the aqueous and gaseous chemistry. Regionally, the monthly mean aerosol burden can vary by a factor of 2 from one year to another, because of different weather conditions, driving chemistry, transport and wet deposition of sulphate aerosols. Sulphate ground concentrations, scavenging fluxes and precipitation modelled were compared with observations. The model represents quite well sulphate fields over Europe, but has a general tendency to overestimate sulphate ground concentrations, in particular over Northern Europe. We assume that it is linked to the representation of the scavenging fluxes, which are underestimated. We suggest that uncertainties in modelled precipitation explain only partially the underestimation of the scavenging fluxes in the model.
\end{abstract}

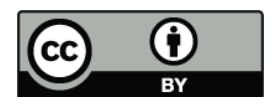

Correspondence to: M. Ménégoz (menegozmartin@yahoo.fr)

\section{Introduction}

Atmospheric aerosols have significant effects on human health (e.g., World Health Organization, 2002) and represent a significant forcing of the Earth's climate (e.g., Haywood and Boucher, 2000). However, their effect on the radiative balance of the earth is rather uncertain, because their burden, particle size distribution and properties are not well known (IPCC, 2007). Sulphate is an aerosol which strongly affects the radiative balance of the atmosphere (e.g. Twomey et al., 1977; Charlson et al., 1992). The sulphate forcing is strongly dependent on sulphate burden and distribution (Koch et al., 1999). According to the work of Kasibhatla et al. (1999), it is strongly linked to the seasonal variation of the column sulphate burden. It is also dependent on the vertical distribution of this aerosol (IPCC, 2007). Consequently, to evaluate the sulphate forcing, it is necessary to estimate the changes in time of the spatial distribution of this aerosol, and therefore to study the sinks and sources of sulphate. This study focuses on the evaluation of sulphate sinks and sources over Europe.

Some aerosols are emitted by natural sources, like dust and sea-salt, and other are emitted by human activities, like Black-Carbon (BC). Some aerosols have both natural and anthropogenic sources, like organic aerosols and sulphates (IPCC, 2007). These two aerosols can be directly emitted into the atmosphere, or produced by chemical reactions, from precursor gases. To represent and understand complex behaviour of aerosols, Chemical Transport Models (CTM) are often used. In particular, many numerical simulations has been performed to describe sulphate distributions, both at global scale (e.g., Kasibhatla et al., 1997; Koch et al.,

Published by Copernicus Publications on behalf of the European Geosciences Union. 
1999; Barrie et al., 2001; Berglen et al., 2004) and regional scale (e.g. Redington and Derwent, 2002; Hass et al., 2003; Schaap et al., 2004). Sulphate mainly originates from the oxidation of anthropogenic and volcanic sulphur dioxide $\left(\mathrm{SO}_{2}\right)$, but also from the oxidation of dimethylsulfide (DMS), produced by marine phytoplankton. Sulphate aerosols have a short lifetime, about 5 days (Lelieveld et al., 1998), and their distributions can change very quickly, due to their strong dependence to meteorological conditions. Regionally, the monthly mean aerosol burden can vary by a factor 2 from one year to the other, because of different weather conditions (Marmer et al., 2007). At the global scale, the results of the aerosol simulations made by existing models differ widely. This is mainly due to the difference in the representation of sources and sinks in each model (Textor et al., 2006). Indeed, models show different annual chemical production of sulphate, depending on the representation of sulphur compounds and oxidants chemistry. The main sink for sulphate is wet deposition (Seinfeld and Pandis, 2006). Its representation is very different from one model to another (Textor et al., 2006), inducing large differences in scavenging fluxes and therefore in sulphate burden modelled.

For this study, we have performed a six-year global simulation, from 2000 to 2005 for dust, BC and sulphate. This paper focuses on the variability of the sulphate distribution over Europe, a place where sulphate comes mainly from $\mathrm{SO}_{2}$ oxidation and where a lot of observations are available. In a first part, we introduce the CTM that we have used and the main parameterisations linked to the atmospheric aerosols. Then, the variability of the sulphate concentration over Europe is evaluated and its link with the main sinks and sources is studied. Finally, modelled sulphate concentrations and surface scavenging fluxes are compared with observations. These comparisons are used to discuss the capacity of the model used to represent sulphate sinks and sources.

\section{Experimental setup}

For this study, we have used the MOCAGE (Modèle de Chimie Atmosphérique de Grande Echelle) (Teyssèdre et al., 2007) CTM of Météo-France. MOCAGE is used for a range of applications, from regional studies of air quality to global analyses of the evolution of both the stratosphere and the troposphere. MOCAGE can perform simulations with nested domains, the parent global grid providing fully-consistent boundary conditions to the inner grids. Here, we present a version which was adapted to represent trace gases and aerosols at the global scale.

\subsection{General features of the MOCAGE CTM}

In our simulation, MOCAGE is used with a T42 Gaussian grid (about $2.8^{\circ} \times 2.8^{\circ}$ horizontal resolution) and with 47 layers from the surface to $5 \mathrm{hPa}$. 7 levels are within the plane- tary boundary layer (PBL), 20 in the free troposphere and 20 in the stratosphere. The vertical coordinate is hybrid $(\sigma, P)$. The first layer is $40 \mathrm{~m}$ thick, while the resolution above $300 \mathrm{hPa}$ is constant with altitude, around $800 \mathrm{~m}$. In our simulation, the air temperature, humidity, pressure and wind components used to drive MOCAGE consist in the 6-hourly analyses of the European Centre for Medium-Range Weather Forecasts (ECMWF) IFS model. A semi-lagrangian scheme is used for the advection of tracers and chemical compounds. It is based upon the work of Williamson and Rasch (1989) and it is not supposed to conserve mass as soon as the grid is irregular. A simple correction scheme is therefore applied in order to ensure total mass conservation during transport. Further details on the transport in MOCAGE are presented in Josse et al. (2004), which has validated MOCAGE transport comparing modelled and observed radon field. Time steps are $1 \mathrm{~h}$ for advection and $15 \mathrm{~min}$ for subgrid-scale processes. Turbulent diffusion follows Louis (1979), while the convection scheme (mass-flux type) is that of Bechtold et al. (2001). The representation of dry-deposition, based on the work of Wesely (1989) is presented in Michou and Peuch (2002). Incloud and below-cloud scavenging representation for gases is presented in Teyssèdre et al. (2007). For this study, we used a version of MOCAGE which can simulate the evolution of three types of aerosols: black-carbon, dust and sulphate. The representation of these aerosols in MOCAGE is described in the next paragraphs.

\subsection{Emissions and representation of aerosol distributions}

$\mathrm{BC}$ and dust are chemically inert in the atmosphere (IPCC, 2007). For this reason, these aerosols are directly emitted in the atmosphere, without being involved in chemical reactions in our model. Sulphate aerosols are both directly emitted in the atmosphere and produced by the oxidation of $\mathrm{SO}_{2}$, DMS and hydrogen sulphide $\left(\mathrm{H}_{2} \mathrm{~S}\right)$. For our six-year simulation, we have used the "AEROsol Comparisons between Observations and Models" (AEROCOM) global inventory representative of the year 2000 (Dentener et al., 2006). Emissions of $\mathrm{SO}_{2}, \mathrm{H}_{2} \mathrm{~S}$ and $\mathrm{SO}_{4}^{2-}$ are constant over the year, except for biomass burning emissions, which have monthly variations. Daily variations of DMS and dust are present in the AEROCOM inventory. However, we have used monthly averages for these fields because we assumed that daily variations of these emissions are very different from one year to the other, and it would not make sense to do our six-year simulation with the daily variation of the year 2000 . We assumed that $2.5 \%$ of the anthropogenic elementary sulphur is directly emitted as $\mathrm{SO}_{4}^{2-}$; the rest being $\mathrm{SO}_{2}$. To avoid too strong vertical gradients within the PBL, emissions are distributed in the five lowest levels of the model, up to an altitude of $600 \mathrm{~m}$ on average.

Our study focuses on the analysis of sulphate sinks and sources. For this reason, we did not take into account the 
Table 1. Diameters, standard deviation and number fraction of log-normal distribution for mineral dust, black-carbon and sulphate based on AEROCOM indications (first column); Distribution in size-bins used in MOCAGE model (second column).

\begin{tabular}{lll}
\hline Aerosol & $\begin{array}{l}\text { Distribution (diameter }(\mu \mathrm{m})- \\
\text { standard- deviation }- \text { number } \\
\text { fraction) }\end{array}$ & Size bins used in the model $(\mu \mathrm{m})$ \\
\hline $\begin{array}{l}\text { Mineral dust } \\
\text { modes }\end{array}$ & $0.22-1.59-0.38$ & 5 bins \\
& $0.63-2.0-0.62$ & $\begin{array}{l}(0.01 \text { to } 0.0631 / 0.0631 \text { to } 0.398 / 0.398 \text { to } 2.51 / 2.51 \text { to } \\
15.8 / 15.8 \text { to } 100)\end{array}$ \\
\hline Black-Carbon & $0.015-1.8-0.92$ & 4 bins \\
modes & $0.040-1.8-0.08$ & $(0.001$ to $0.01 / 0.01$ to $0.1 / 0.1$ to $1 / 1$ to 10$)$ \\
\hline Sulphate modes & $0.015-1.8-0.98331$ & 4 bins \\
& $0.04-1.8-0.01650$ & $(0.001$ to $0.01 / 0.01$ to $0.1 / 0.1$ to $1 / 1$ to 10$)$ \\
& $0.5-2-0.00019$ & \\
\hline
\end{tabular}

dependence of dust emissions on wind velocities in our simulation. A scheme describing wind-dependent dust emissions has been implemented in the model MOCAGE. It is presented and validated in Martet (2009).

The AEROCOM inventory used in our study describes the quantity of aerosols and precursor gases emitted in the atmosphere. It also provides a distribution for each type of aerosol. This distribution is a sum of log-normal distributions. Diameter, standard deviation and fraction number of these different modes are presented in the first column of Table 1 for each aerosol. In our model, aerosol log-normal distributions are discretized into bins of different sizes, as described in Martet (2009). The chemical production of sulphate and the direct emissions of black-carbon and mineral dust are injected into the atmosphere following the bin distributions defined in the second column of Table 1. Bins are wide enough to cover entirely the log-normal distributions suggested by the AEROCOM project, both in term of number and mass fraction distributions.

Some types of aerosols are not yet taken into account in our model, as for example organic aerosols. Aerosols are assumed to be externally mixed in our simulation, each one evolving independently from the others in our simulation. This simplified approach can be criticized because it does not describe perfectly the real aerosol distribution and composition. However, the interactions between the different types of aerosols are second-order processes compared to transport, emissions, wet deposition and chemistry, which need to be well represented to correctly simulate sulphate aerosol (Trivitayanurak et al., 2008). The major part of the atmospheric black-carbon is mixed with the other aerosols, especially with sulphate, which can strongly affect its lifetime. This is not the case of sulphate, because only $20 \%$ of non seasalt sulphate is internally mixed with other aerosols, the rest evolving independently from the other aerosols (Liu et al., 2005). Our approach is simplified, but it allows to perform global simulations at a reasonable computational cost. We assume this description of aerosol distribution is reasonable to evaluate the aerosols fluxes in global and regional simulations at first order, especially for sulphate aerosol which concerns this study. The representation of the chemical and physical processes concerning aerosols in our model is described in the following.

\subsection{Sulphur chemistry}

Several chemical scheme are available running MOCAGE. For global simulations of atmospheric oxidants, a full chemical scheme describing the evolution of 82 gaseous species throughout 242 chemical reactions is used. It is a combination of the tropospheric scheme RELACS (Crassier et al., 2000) and of the stratospheric scheme REPROBUS (Lefèvre et al., 1994). In our study, we used a simple chemical scheme, that considers the sulphur cycle only, based on Pham et al. (1995). The sulphur cycle is described with nine chemical reactions that involve eleven species (see Fig. 1). The oxidants $\left(\mathrm{OH}, \mathrm{H}_{2} \mathrm{O}_{2}, \mathrm{O}_{3}\right.$ and $\left.\mathrm{NO}_{3}\right)$ are provided by a oneyear MOCAGE simulation with the full chemical scheme. The oxidation reactions described, both in the gaseous and aqueous phases, lead to the formation of sulphate $\left(\mathrm{SO}_{4}^{2-}\right)$, that condensate quasi-instantaneously into aerosol particles.

\subsection{Physics of aerosols in the model}

Aerosols are removed from the atmosphere by three main sinks: dry deposition, due to the contact of the atmospheric flow with the earth surface, sedimentation, implied by gravitational forces, and wet deposition, due to the presence of water droplet in the atmosphere (Seinfeld and Pandis, 2006). In the following, we describe the parameterisations of these processes that we used.

Parameterisation of the dry-deposition is based on Seinfeld and Pandis (2006), and its adaptation in MOCAGE is 


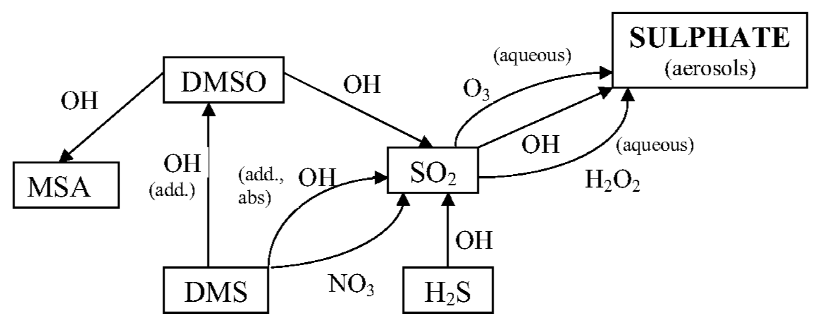

Fig. 1. The sulphate chemistry used within MOCAGE. All reactions are in the gaseous phase except for the $\mathrm{SO}_{2}$ oxidation by $\mathrm{O}_{3}$ and $\mathrm{H}_{2} \mathrm{O}_{2}$ which occur in the aqueous phase.

presented in Nho et al. (2004). The velocity sedimentation is computed from the Stokes law, adapted for the atmosphere in Seinfeld and Pandis (2006).

MOCAGE describes both below-cloud and in-cloud scavenging. A collision efficiency between aerosols and droplets is computed to determine below-cloud scavenging. It depends on the Reynolds and Schmidt numbers and on the ratio of aerosol and droplet diameters, as presented in Seinfeld and Pandis (2006). In-cloud scavenging is the adsorption of particles by cloud droplets. Its efficiency depends on the aerosol composition. For each grid cell, a scavenging rate $\lambda$ is computed (Langner and Rodhe, 1991):

$\lambda=\frac{\varepsilon \times R}{L}$

$R$ is the precipitation formation rate and $L$ is the cloud Liquid Water Content (LWC). $\varepsilon$ is a coefficient empirically proportional to $L$ :

$\varepsilon=\alpha \times L$

Kasper-Giebl et al. (2000) observed the dependence of $\varepsilon$ to $L$ in clouds for BC and sulphate aerosols (see Fig. 2). For our study, we computed $\varepsilon$ from a simple fit on these observations (see red lines in Fig. 2):

$\varepsilon_{\mathrm{BC}}=1.2 L$ for $\mathrm{LWC} \leq 0.6 ; \varepsilon_{\mathrm{BC}}=0.6$ for $\mathrm{LWC}>0.6$

$\varepsilon_{\text {sulphate }}=3 L$ for $\mathrm{LWC} \leq 0.3 ; \varepsilon_{\text {sulphate }}=0.9$ for $\mathrm{LWC}>0.3$

We have to underline that in-cloud scavenging is a crucial process in aerosol simulations, especially for sulphate. For this aerosol, it represents $95 \%$ of the total scavenging (Boucher et al., 2002). Consequently, the sulphate distributions modelled are strongly dependent on the representation of this sink.

\section{Seasonal and inter annual variability of the sulphate burden over Europe}

We computed a six-year simulation at the global scale, but for the purpose of this study, we consider a domain centred over Europe, between $30^{\circ} \mathrm{W}$ to $40^{\circ} \mathrm{E}$ in longitude and $30^{\circ} \mathrm{N}$ to $85^{\circ} \mathrm{N}$ in latitude.

\subsection{Variations of the sulphate burden}

Figure 3a shows the weekly moving average of the sulphate burden over Europe for the 6 years of the simulation. Our simulation was initialised with all aerosol concentrations set to zero. A three-month spin-up is required for the sulphate burden to reach an equilibrium value. Lifetimes of tropospheric aerosols vary from several days to several weeks (Delmas et al., 2005), so we can assume that after this threemonth spin-up, the aerosol distributions of the model should be realistic. Since we used the same emissions of sulphate precursors for each year of the simulation, the variations of the sulphate burden are only due to the variations of meteorological fields. The sulphate burden shows a significant annual cycle. For each year of the simulation, the sulphate burden reaches a maximum around May, twice stronger than a minimum value which occurs around September. The maximum is around $9 \mathrm{mg}[\mathrm{S}] \mathrm{m}^{-2}$ ( \pm 0.5 depending on the year), and the minimum value is around $4 \mathrm{mg}[\mathrm{S}] \mathrm{m}^{-2}( \pm 0.5 \mathrm{de}$ pending on the year). A simulation made by the regional model REMOTE over Europe for the years 2002 and 2003 presented in (Marmer et al., 2007) shows an annual cycle between $2 \mathrm{mg}[\mathrm{S}] \mathrm{m}^{-2}$ and $0.8 \mathrm{mg}[\mathrm{S}] \mathrm{m}^{-2}$. These values are about 4 times lower than ours. Moreover, in this REMOTE simulation, the annual cycle is shifted, with a maximum in July and a minimum in January. In their paper, Marmer et al. (2007) find an anti-correlation between precipitation and sulphate burden.

Figure $3 b$ shows the weekly moving average of precipitation. Precipitation has a significant variance, stronger than that of sulphate burden (see Fig. 3a). However, it shows a significant annual cycle, with a maximum close to the end of the year, and a minimum around June. The maximum sulphate burden occurs about three months after the maximum of precipitation. It is difficult to correlate precipitation with sulphate because if high precipitation implies large scavenging rates on the one hand, it corresponds to a significant aqueous chemistry production of sulphate because of the high LWC of the atmosphere on the other hand. Moreover, the variance of precipitation is higher than those of sulphate burden over Europe.

\subsection{Evaluation of the sulphate sinks and sources}

Figure 4 shows the sulphur budget over the domain considered in this study (between $30^{\circ} \mathrm{W}$ to $40^{\circ} \mathrm{E}$ in longitude and $30^{\circ} \mathrm{N}$ to $85^{\circ} \mathrm{N}$ in latitude). The main source of sulphur is due to anthropogenic $\mathrm{SO}_{2}$ emissions. $\mathrm{DMS}, \mathrm{H}_{2} \mathrm{~S}$ and sulphate direct emissions are of the same order of magnitude, approximately 20 times lower than $\mathrm{SO}_{2}$ emissions. The main sink for $\mathrm{SO}_{2}$ is dry deposition $\left(229.13 \mathrm{mg}[\mathrm{S}] \mathrm{m}^{-2}\right.$ year $\left.^{-1}\right)$, followed by aqueous chemistry $\left(200.56 \mathrm{mg}[\mathrm{S}] \mathrm{m}^{-2}\right.$ year $\left.^{-1}\right)$, then by wet deposition $\left(68.75 \mathrm{mg}[\mathrm{S}] \mathrm{m}^{-2}\right.$ year $\left.^{-1}\right)$, gaseous chemistry $\left(61.95 \mathrm{mg}[\mathrm{S}] \mathrm{m}^{-2}\right.$ year $\left.^{-1}\right)$ and export out of the domain (41.62 $\mathrm{mg}[\mathrm{S}] \mathrm{m}^{-2}$ year $^{-1}$ ). Aqueous phase $\mathrm{SO} 2$ oxidation is 

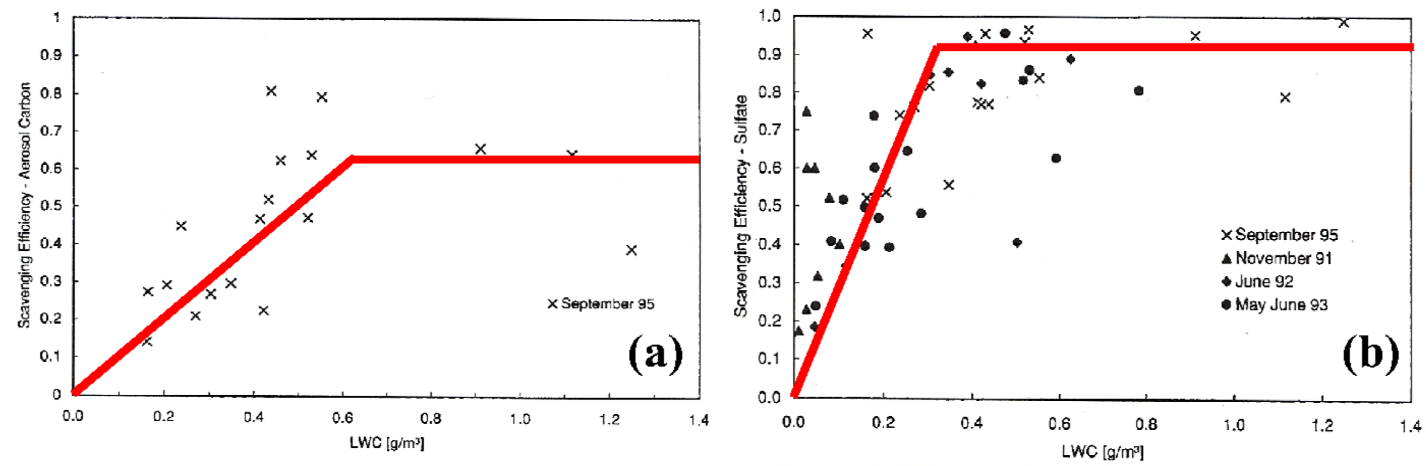

Fig. 2. Scavenging efficiencies of Black-Carbon (a) and sulphate (b) in supercooled Clouds at Mt. Sonnblick (Adapted from Kasper-Giebl et al., 2000).

Table 2. Burden $\left(\mathrm{mg}[\mathrm{S}] \mathrm{m}^{-2}\right)$, sources and sinks of sulphate $\left(\mathrm{mg}[\mathrm{S}] \mathrm{m}^{-2}\right.$ day $\left.^{-1}\right)$ over Europe simulated by Kasibhatla et al. (1997) model and MOCAGE. Domain of Kasibhatla et al. covers $40^{\circ} \mathrm{N}-60^{\circ} \mathrm{N}, 10^{\circ} \mathrm{W}-40^{\circ} \mathrm{E}$, this study domain covers $30^{\circ} \mathrm{N}-85^{\circ} \mathrm{N}, 30^{\circ} \mathrm{W}-40^{\circ} \mathrm{E}$.

\begin{tabular}{lccccccccccc}
\hline & \multicolumn{2}{c}{ Burden } & \multicolumn{2}{c}{ Total chemical production } & \multicolumn{2}{c}{ Wet deposition } & \multicolumn{2}{c}{ Dry deposition } & Export \\
\hline & summer & winter & summer & winter & summer & winter & summer & winter & summer & winter \\
\hline This study (MOCAGE) & 5.26 & 5.32 & 0.7 & 0.76 & 0.34 & 0.36 & 0.13 & 0.17 & 0.30 & 0.27 \\
Kasibhatla et al. (1997) & 4.7 & 2.9 & 2.7 & 2.2 & 1.6 & 1.1 & 0.3 & 0.3 & 0.7 & 0.8 \\
\hline
\end{tabular}

the main source for sulphate $\left(200.56 \mathrm{mg}[\mathrm{S}] \mathrm{m}^{-2}\right.$ year $\left.^{-1}\right)$, followed by gaseous oxidation $\left(61.95 \mathrm{mg}[\mathrm{S}] \mathrm{m}^{-2}\right.$ year $\left.^{-1}\right)$ and direct emissions $\left(12.41 \mathrm{mg}[\mathrm{S}] \mathrm{m}^{-2}\right.$ year $\left.^{-1}\right)$. The main sulphate sinks are wet deposition $\left(127.22 \mathrm{mg}[\mathrm{S}] \mathrm{m}^{-2}\right.$ year $\left.^{-1}\right)$, followed by the export ( $96.62 \mathrm{mg}[\mathrm{S}] \mathrm{m}^{-2}$ year $\left.^{-1}\right)$ and dry deposition $\left(50.89 \mathrm{mg}[\mathrm{S}] \mathrm{m}^{-2}\right.$ year $\left.^{-1}\right)$.

Figure $3 \mathrm{~d}$ shows the times series of sinks and sources of sulphate over Europe: the aqueous and gaseous chemistries present a significant annual cycle. In winter, the production by the aqueous chemistry is the main source of sulphate, whereas the production by the gaseous chemistry is negligible. In contrast, the production of the gaseous and aqueous chemistries are similar in summer. Production by aqueous chemistry is clearly correlated with precipitation (see Fig. 3b and d): when precipitation is intense, the atmospheric LWC is high, sulphur compounds are diluted and the aqueous chemistry is efficient. The production by the gaseous chemistry, which presents maxima in summer and minima in winter, is clearly correlated with temperature (see Fig. 3c and d).

The main sink for sulphate is wet deposition, due to its high solubility. Wet deposition is proportional to sulphate concentration, but also depends on cloud LWC, which is correlated with precipitation. It does not have a clear annual cycle, but is generally higher in winter, a period with stronger precipitation than in summer. Dry deposition is three times smaller than wet deposition and sedimentation is negligible for sulphate aerosols. A significant amount of sulphate is ad- vected out of the European domain (see the curve "Export" in Fig. 3d). The direct emissions are very small compared to the chemical production. The sulphate burden variations load, that appears in black in Fig. 3d, oscillate around zero.

A maxima in sulphate burden appears at the end of winter due to the combination of a maxima in the total chemical production (aqueous and gaseous) and low scavenging values. Minima in sulphate burden appears at the beginning of autumn due to the combination of a minima in the total chemical production and high scavenging fluxes relatively to sulphate burden. Kasibhatla et al. (1997) have yet estimated burden, sources and sinks over a European domain. Table 2. compares the burden and the different sulphate fluxes simulated for the two studies. If our study shows an equivalent sulphate burden between the winter and the summer, those of Kasibhatla et al. shows a sulphate burden two times higher in summer than in winter. We have to keep in mind that the domain taken into account in our study is larger and contains more oceanic surfaces than those chosen by Kasibhatla et al. (1997). As a consequence, the anthropogenic $\mathrm{SO}_{2}$ emissions, the total chemical production and the sulphate flux advected out of the European domain are lower considering our domain instead those of Kasibhatla et al. (1997). Dry and wet deposition are also smaller in our study, and it. explains that sulphate burden in our simulation is higher than those of Kasibhatla et al. (1997). All sulphate fluxes averaged over summer and winter are quite similar in our simulation, whereas total chemical production and wet deposition vary 
a)

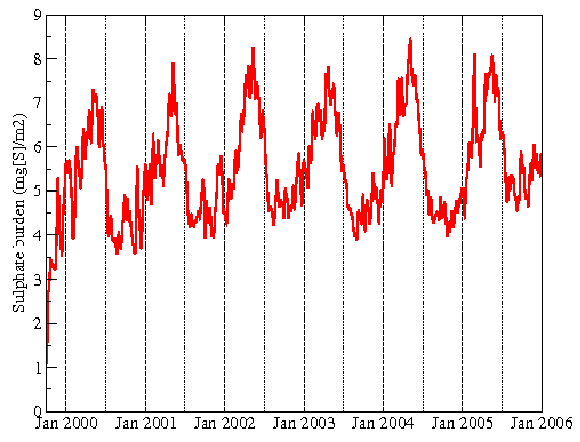

b)

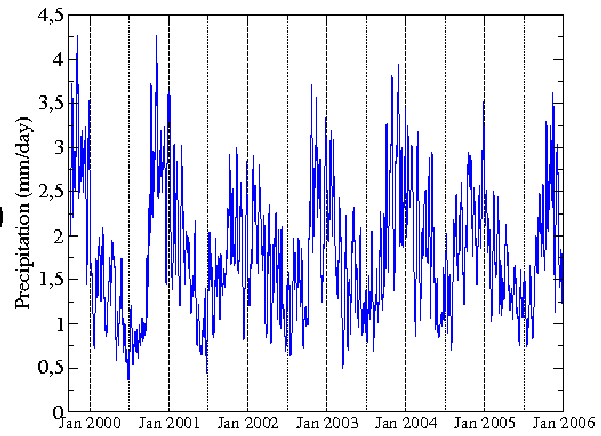

c)

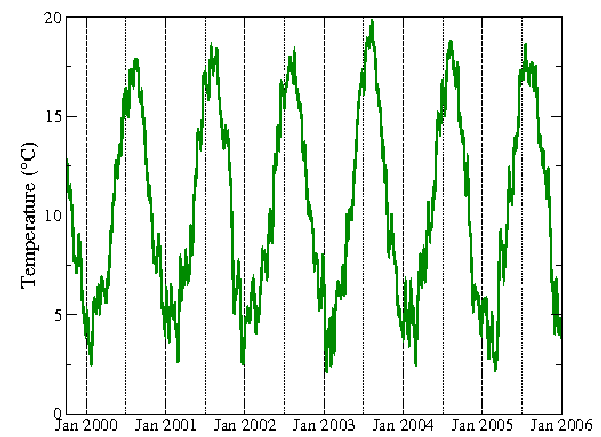

d)

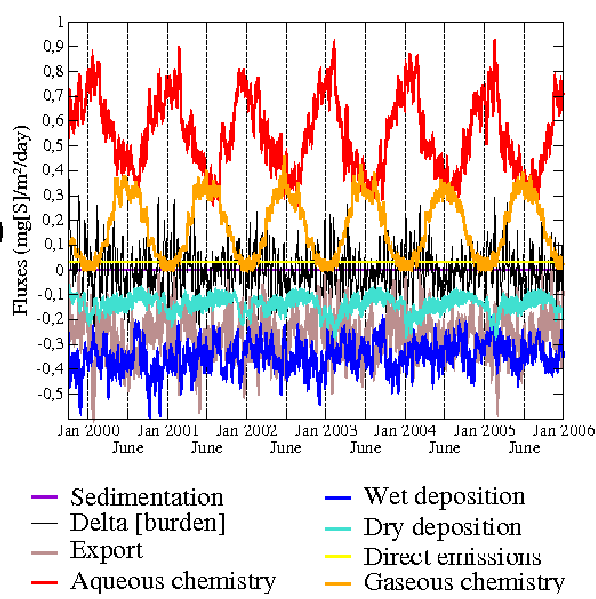

Fig. 3. (a) Sulphate burden $\left(\mathrm{mg}[\mathrm{S}] \mathrm{m}^{-2}\right)$, (b) precipitation $\left(\mathrm{mm} \mathrm{day}^{-1}\right)$, (c) temperature $\left({ }^{\circ} \mathrm{C}\right),(\mathbf{d})$ sinks and sources of sulphate $\left(\mathrm{mg}[\mathrm{S}] \mathrm{m}^{-2} \mathrm{day}^{-1}\right.$, see text for details) averaged over our European domain, from October, 1999 to December, 2005 (weekly moving averages applied to 6 hourly model outputs).

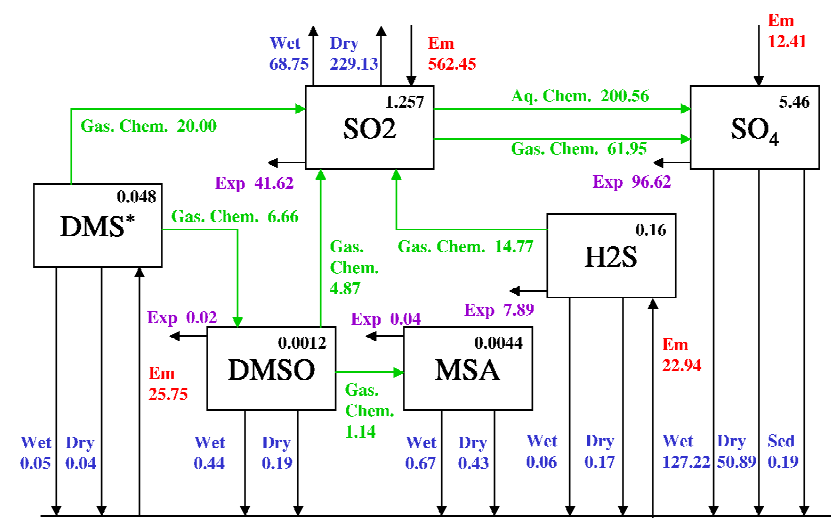

Fig. 4. Sulphur annual budget over Europe $\left(30^{\circ} \mathrm{W}\right.$ to $40^{\circ} \mathrm{E}$ and $30^{\circ} \mathrm{N}$ to $85^{\circ} \mathrm{N}$ ) simulated by MOCAGE. Burden, written on the square containing the compound name are in $\mathrm{mg}[\mathrm{S}] \mathrm{m}^{-2}$. Fluxes are in $\mathrm{mg}[\mathrm{S}] \mathrm{m}^{-2}$ year $^{-1}$. Gas. Chem.: Gaseous Chemistry; Aq. Chem: Aqueous chemistry; Wet: Wet deposition; Dry: Dry deposition; Exp: Export; Em: Emissions.

from about $25 \%$ between winter and summer in Kasibhatla et al. (1997). In their study, the gaseous production presents an annual cycle comparable as our, which a maximum in summer and a minimum in winter (not shown). It is not the case for the aqueous chemistry, which shows few variations between summer and winter in their study in comparison with our simulation (not shown). In our simulation, the combination of the annual cycles of the aqueous and gaseous chemical production leads to a total chemical production relatively constant over the year.

The AEROCOM inventory is characterised by strong emissions over two rgions: Eastern Europe and Southern Europe (not shown). In the East of the continent, emissions are mainly anthropogenic. In the South, there are also anthropogenic emissions around the Mediterranean sea, but according to the AEROCOM inventory, emissions from the Etna volcano are also regionally very strong.

Figure 5 shows maps of the column and the main sinks and sources for sulphate over Europe. In January, the column of sulphate presents high values in North-Eastern Europe (Fig. 5a). In this region and during this month, the atmosphere is humid enough to favour high levels of aqueous production of sulphate (Fig. 5b), but not enough to imply high scavenging rates. As a consequence, removal by wet deposition (Fig. 5d) is limited over North-Eastern Europe in January. In July, the total column of sulphate presents high values in Southern Europe (Fig. 5a). The atmosphere is then dry there, so sulphate production comes essentially from the gaseous chemistry (Fig. 5c), and scavenging fluxes are small (Fig. 5d). In contrast, more humid conditions in Eastern Europe, close to anthropogenic emissions, result in larger scavenging fluxes (Fig. 5d). 
JANUARY

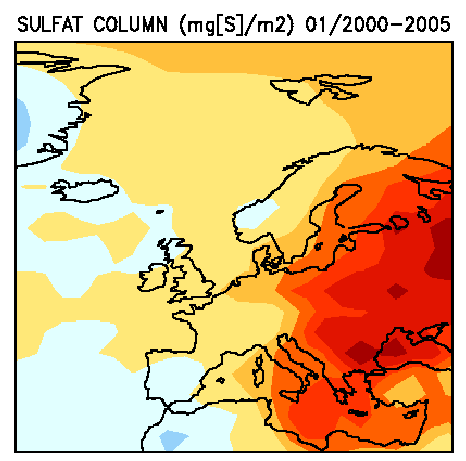

AQU. CHEM. PROD. (mg[S]/m2/day) 01/2000-2005

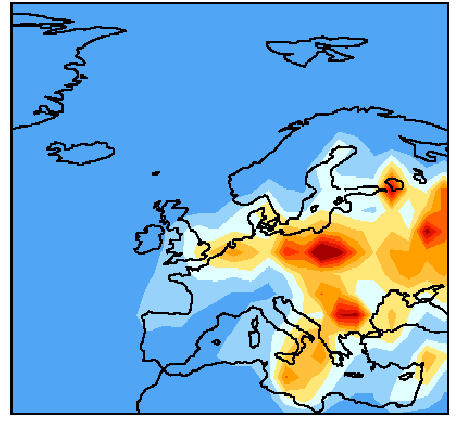

GAS. CHEM. PROD, (mg[S]/m2/day) 01/2000-2005

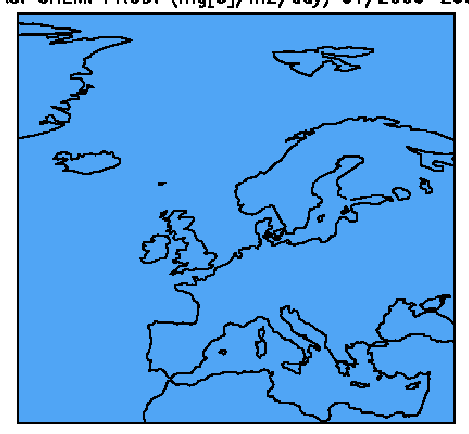

WET DEPOSITION (mg[S]/m2/day) 01/2000-2005

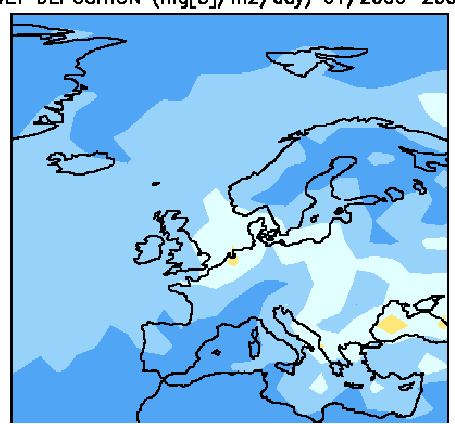

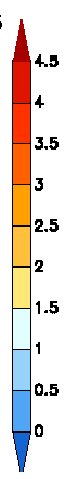
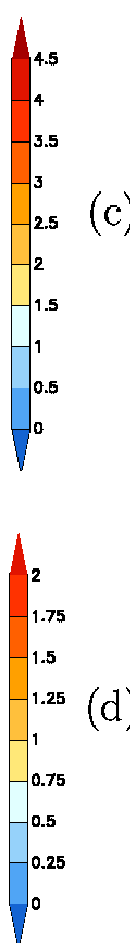

\section{JULY}

SULFAT COLUMN (mg[s]/m2) 07/2000-2005

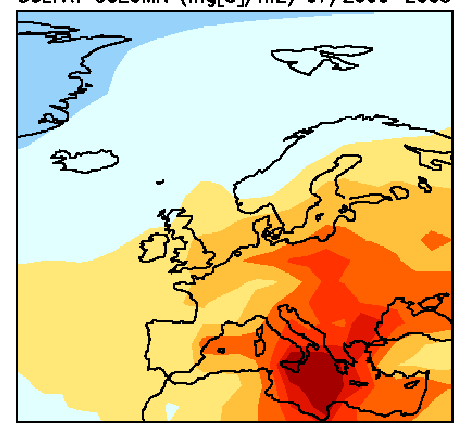

AQU. CHEM. PROD. (mg[S]/m2/day) 07/2000-2005

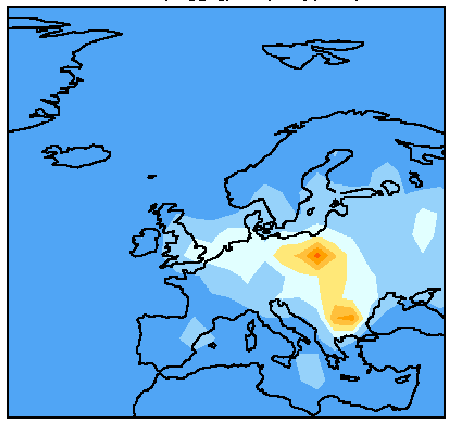

GAS. CHEM. PROD. (mg[S]/m2/day) $07 / 2000-2005$

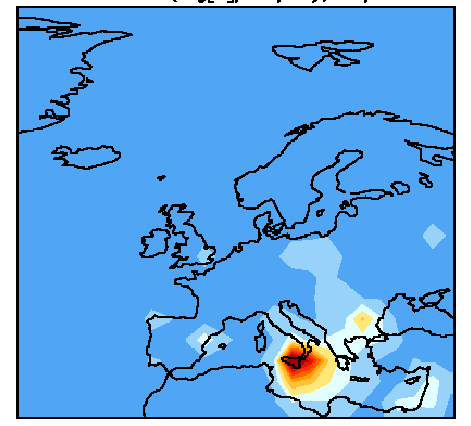

WET DEPOSITION (mg[S]/m2/day) 07/2000-2005

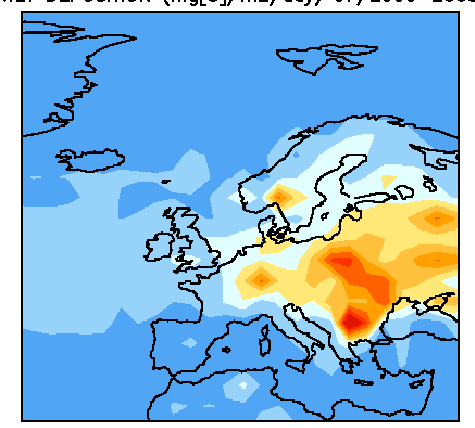

Fig. 5. From top to bottom: (a) Column of sulphate, (b) production by aqueous chemistry, (c) production by gaseous chemistry, (d) scavenging fluxes. Field averaged over the 2000-2005 period for January (left) and July (right). The sulphate column is in units of $\mathrm{mg}[\mathrm{S}] \mathrm{m}^{-2}$; other quantities are in $\mathrm{mg}[\mathrm{S}] \mathrm{m}^{-2} \mathrm{day}^{-1}$. 

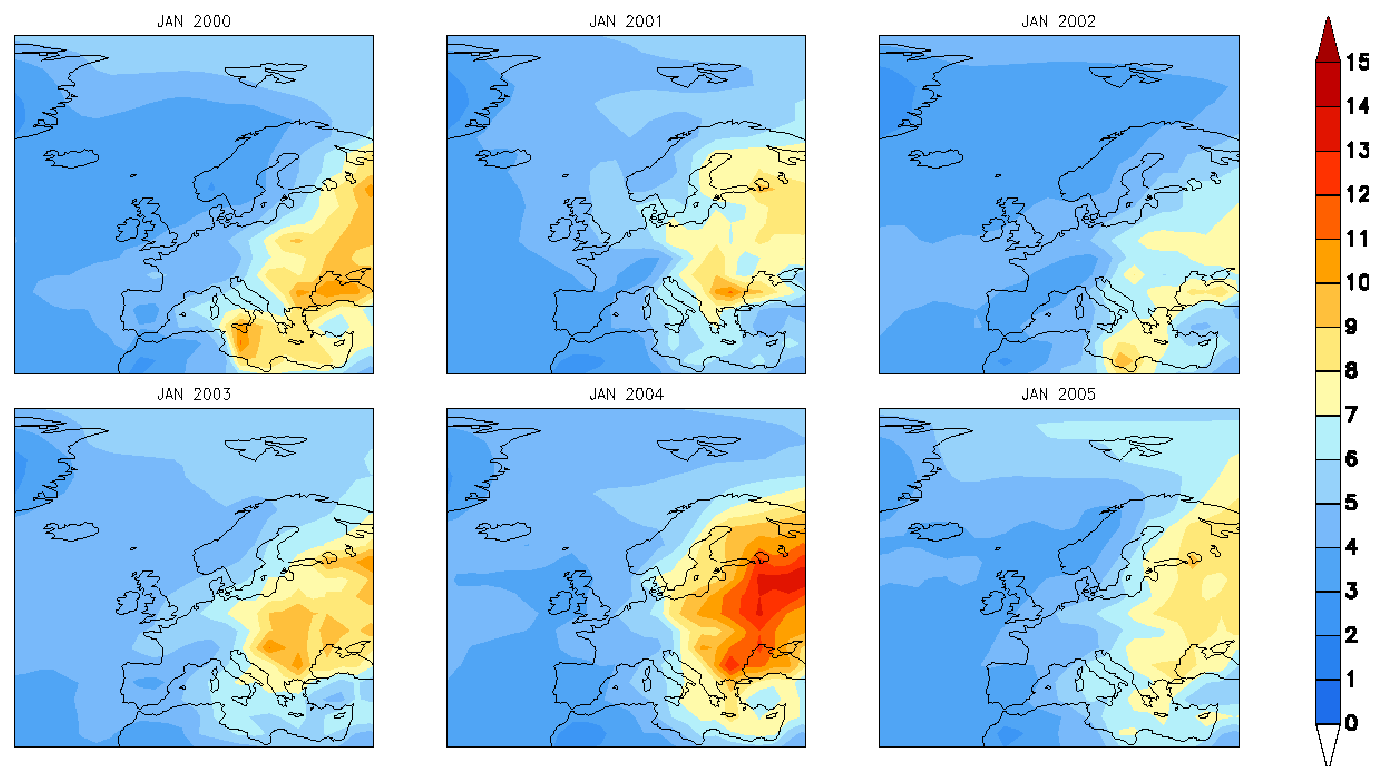

Fig. 6. Mean sulphate column $\left(\mathrm{mg}[\mathrm{S}] \mathrm{m}^{-2}\right)$ over Europe in January from 2000 to 2005.
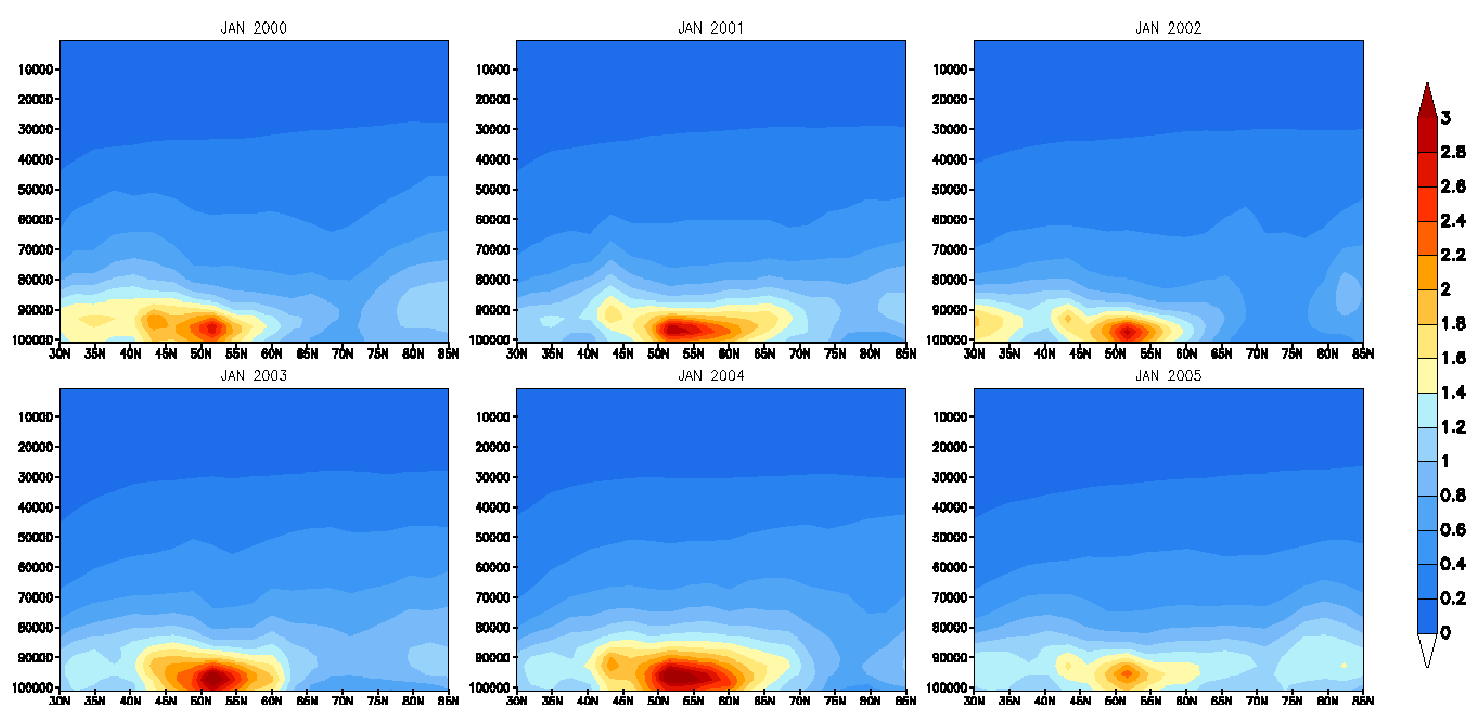

Fig. 7. Sulphate zonal mean $\left(\mathrm{mg}[\mathrm{S}] \mathrm{m}^{-3}\right)$ over Europe, January of years 2000 to 2005. (levels are in Pa).

\subsection{Evolution of the sulphate distribution over the six-year simulation}

As we used constant emissions over our six-year simulation, the modelled interannual variability of the sulphate distributions is caused by the variability of the meteorological fields. Figures 6 and 7 show the variability of sulphate in January over the period 2000-2005, respectively in terms of column and zonal mean. As explained previously, sulphate concentrations are high on the East of the domain that we considered in Januray, due to a strong aqueous chemistry production. Figure 6 shows that the sulphate column can vary locally by a factor 2 in January from one year to the next. To throw some light on, time series sulphate sinks and sources during the 2001-2002 and 2003-2004 winters (respectively named W1 and W2) are shown in Fig. 8. Differences between W1 and W2 in sulphate distributions are mainly the consequence of two factors: in December 2001-January 2002, large amount of sulphate are transported outside of the domain (see variable "Export" in Fig. 8), in contrast with the same period in 2004, when most of the sulphate produced is accumulated over polluted areas. Moreover, the aqueous chemistry production of sulphate is stronger in January 2004 than in Jan- 
uary 2002, in particular during the second half of the month. Figure 8 shows also that the wet deposition is stronger in 2004 than in 2002 during the first two weeks of January, but not enough to allow the sulphate burden to reach the 2002 values.

Figure 9 shows the monthly mean meteorological fields of January 2002 and 2004. January 2002 has high pressures over Southern Europe and low pressures over Northern Europe (Fig. 9a). In contrast, January 2004 shows high pressures in the South-Western part of the domain only. The larger transport of aerosol out of the domain in 2002 compared to 2004 is linked to strong westerly winds above Eastern Europe (Fig. 9b), a zone with high levels of sulphate. On the contrary, field of temperature of the two years are quite similar during January (Fig. 9c) and we can assume that they do not explain the differences in the sulphate chemistry production. Figure 9d shows that precipitation is slightly higher in Eastern Europe in January 2004 than in January 2002; Atmospheric LWC approximately follows the same behaviour as precipitation. This implies a stronger sulphate aqueous chemistry production in Eastern Europe in January 2004 (Fig. 10a), where $\mathrm{SO}_{2}$ emissions are high. Wet deposition is also larger in January 2004 than in January 2002, but only in parts of Eastern Europe (Fig. 10b). This comparison confirms that the meteorological fields can locally affect sulphate concentration strongly, depending on the relative positions of the atmospheric pressure patterns and the location of the $\mathrm{SO}_{2}$ emissions.

Figure 7 shows that the vertical distribution of sulphate does not vary a lot in Europe from one year to the next, unlike their latitudinal. As explained previously, at a given latitude, the zonal mean of sulphate concentration over Europe can vary by a factor 2 , depending on the meteorological forcing. Moreover, we can see in both Figs. 6 and 7 that there is a significant transport of sulphate toward high latitudes in January. Transport of atmospheric air masses from European polluted areas towards the North pole has been highlighted (Stohl, 2006). In our simulation, the sulphate transport towards the Arctic shows significant variations depending on the year considered (Fig. 7).

\section{Comparison between EMEP observations and MOCAGE outputs}

European Monitoring and Evaluation Programme (EMEP) (Hjellbrekke, 2004) observations are used here to validate sulphate concentrations, scavenging fluxes and precipitation simulated by MOCAGE. We have to note that it is not straightforward to compare point measurements with gridded model output. The model, which has a coarse horizontal resolution of about $2.8^{\circ}$, represents an average of sulphate concentration in each grid cell. In our study, these grid values are compared with the mean of all EMEP observations available inside the grid cell.

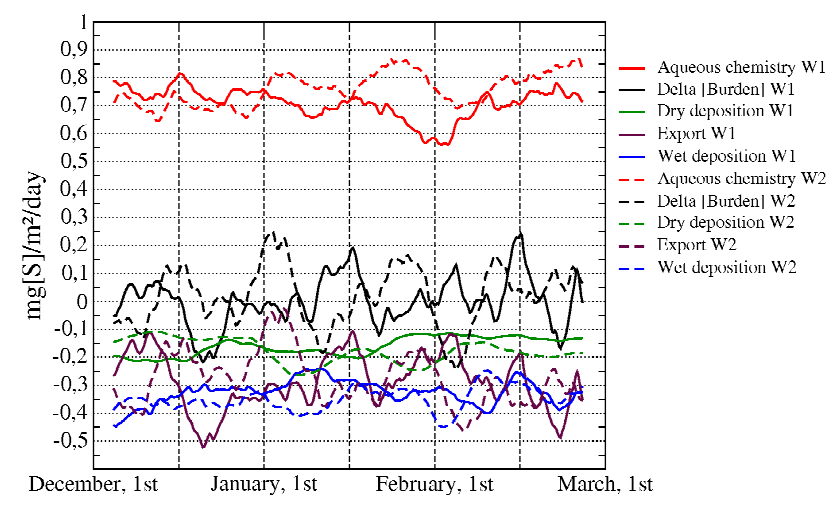

Fig. 8. Mains sulphate sinks and sources for 2001-2002 (W1) and 2003-2004 (W2) winters (weekly moving averages applied to 6 hourly model outputs). Fluxes are in $\mathrm{mg}[\mathrm{S}] \mathrm{m}^{-2}$ day.

Figure 11 represents the sulphate ground concentrations modelled by MOCAGE and observed at the EMEP stations in January and July, averaged over 2000-2005. Generally, the model overestimates sulphate concentrations both in winter and summer: in high sulphate concentrations areas, observed values reach $2 \mu \mathrm{g} \mathrm{m}^{-3}$ whereas they go up to $3 \mu \mathrm{g} \mathrm{m}^{-3}$ in the model. Despite the lake of EMEP observations in Eastern Europe, the spatial agreement seems to be quite good in winter, a period with high concentrations of sulphate over Central and Eastern Europe and low sulphate concentrations in all Western Europe. In summer, the agreement between the model and observations is quite good over Northern Europe, but discrepancies appear in Southern Europe: high sulphate concentrations are simulated near the Etna volcano, due to large emissions in the AEROCOM inventory. It should be noted that, in our model, volcanic emissions are injected in the first five levels only. Injecting them higher would certainly avoid such accumulations near the surface. Nevertheless, there are too few observations in the EMEP network in this region to really assess the Etna contribution. In the South-West of Europe, the model represents sulphate concentrations on the coast quite correctly, but underestimates concentrations over Spain. This underestimation could be due to an underestimation of emissions in this region or to a bad representation of the southward aerosol transport.

Figure 12 shows a comparison between modelled and observed sulphate concentrations for each season, averaged over 2000-2005, and distinguishing between NorthernCentral and Southern Europe. As already noted over Europe, modelled surface concentrations overestimate EMEP observations. This overestimation is more marked in autumn and winter. Moreover, agreement between model and observations is better in southern Europe.

Figure 13 presents similar seasonal comparisons as in Fig. 12, but for scavenging fluxes. We constructed observed scavenging fluxes by multiplying precipitation fluxes with 
JANUARY 2002
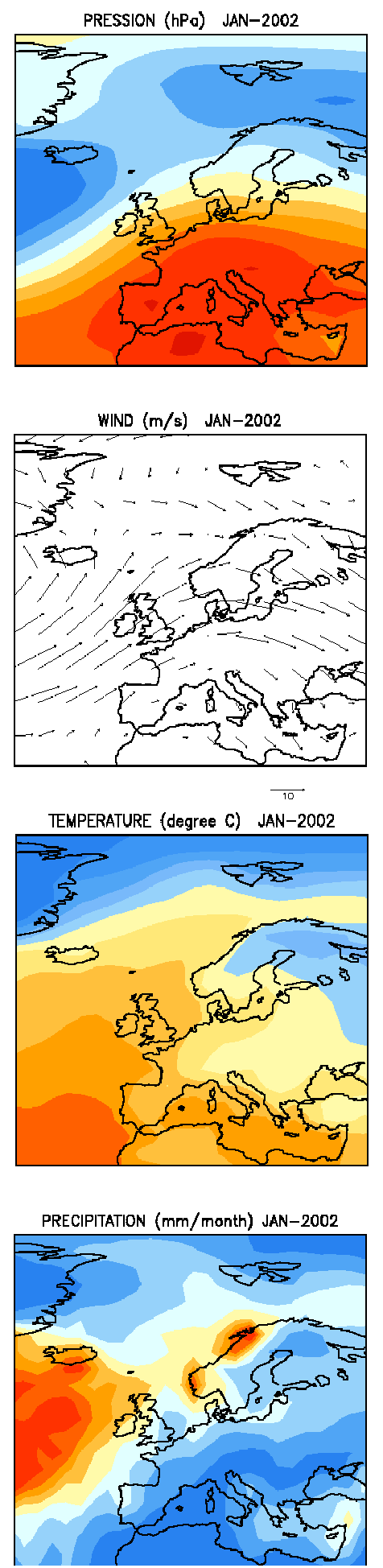

JANUARY 2004

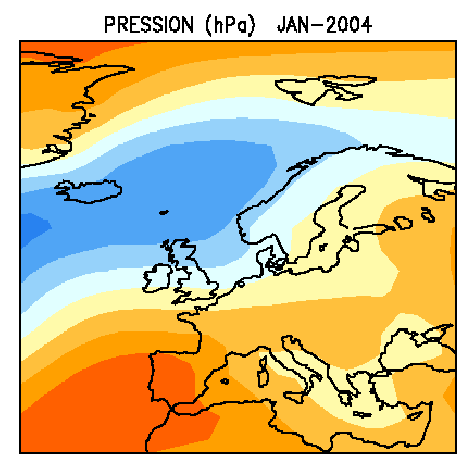

(b)
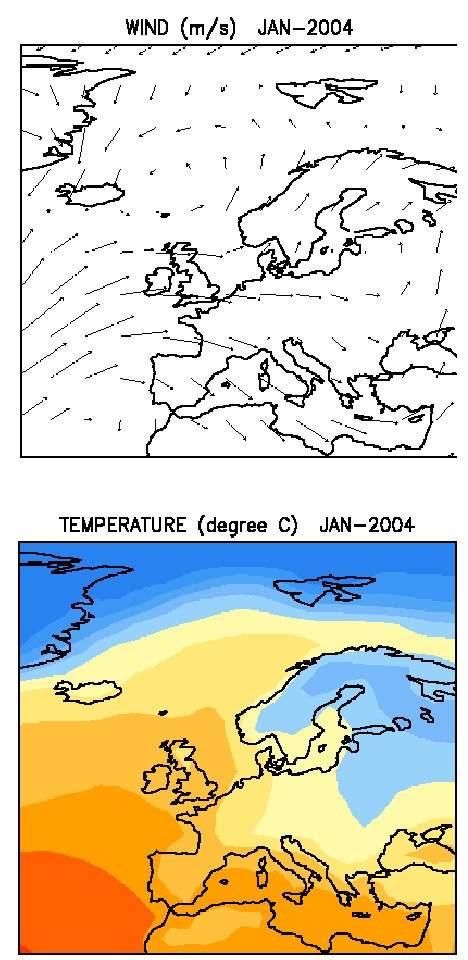

PRECIPITATON (mm/month) JAN-2004

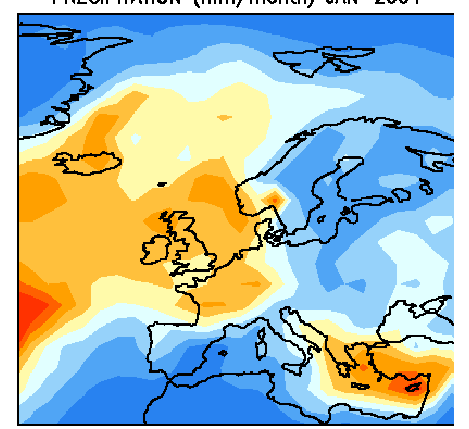

Fig. 9. Meteorological fields for January 2002 (left) and January 2004 (right). From top to bottom: (a) Pressure (hPa), (b) wind (m s $\left.{ }^{-1}\right)$, (c) temperature $\left({ }^{\circ} \mathrm{C}\right)$ and $(\mathbf{d})$ precipitation $\left(\mathrm{mm} \mathrm{month}^{-1}\right)$ fields. 


\section{JANUARY 2002}
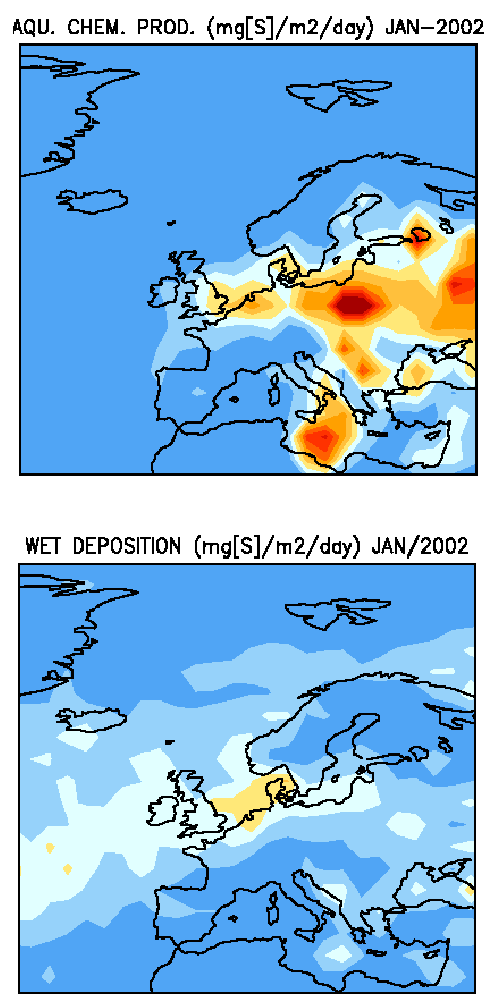

JANUARY 2004
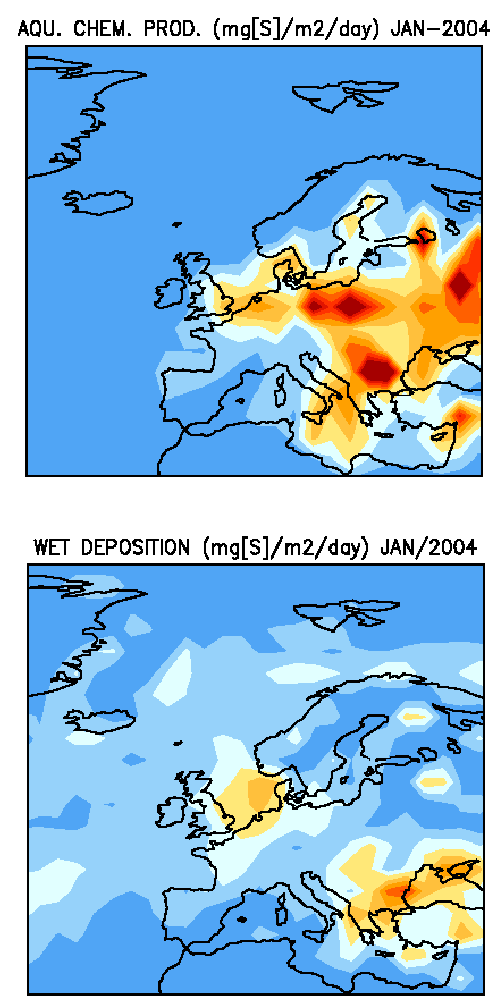

Fig. 10. Distribution of the aqueous chemistry production (a) and the wet deposition (b). January 2002 (left) and January 2004 (right). Fluxes are in $\mathrm{mg}[\mathrm{S}] \mathrm{m}^{-2}$ day $^{-1}$.

sulphate concentration in precipitating water. The modelled fluxes diagnosed by the model correspond to the amount of sulphate absorbed by cloud droplet as presented in Sect. 2.2. Modelled scavenging fluxes generally underestimate observations for all seasons in Southern Europe. In Northern Europe, scavenging fluxes are too low in winter and spring, but are rather correct during the summer and the autumn. Representation of scavenging fluxes is strongly linked with the quality of the representation of cloud LWC and precipitation in models (Textor et al., 2007). Figure 14 shows that high precipitation values are generally underestimated by the model. Agreement between the model and observations is quite good for all seasons, except for winter. For this season, Fig. 14 reveals a large scatter: in Southern Europe, precipitation is often overestimated, and in Northern Europe, if model represents quite correctly low precipitations, it underestimates high precipitation. In addition, the scatter is larger in plots for Southern Europe than for Northern Europe.

In Northern Europe, we can assume that the model overestimates sulphate ground concentrations because it underestimates scavenging fluxes. In Southern Europe, modelled sulphate ground concentration are in better agreement with observations. We can hypothesize that in this region, underestimation of the scavenging fluxes is compensated by an overestimation of emissions. The underestimation of scavenging fluxes in Northern Europe is probably partly linked with the underestimation of precipitations in that area, in particular for high precipitations and high scavenging fluxes situations. But in Southern Europe, scavenging fluxes are underestimated whereas this is not the case for precipitation. This suggests that the scavenging representation is not only dependent on the model capacity to represent precipitation.

\section{Conclusions}

MOCAGE CTM has been used to model aerosol distributions at the global scale. Specific developments have been included in the model to describe sulphate aerosols, in particular a simple chemical scheme describing both the aqueous and gaseous chemistries, using oxidants fields generated by a full chemistry MOCAGE run. The representation of sulphate wet deposition is based on an empirical law, adjusted on measurements made by Kasper-Gibel et al. (2000). A six-year global simulation has been performed using the AEROCOM emissions inventory and the ECMWF operational analyses. Burden, sources and sinks of sulphate in Europe over the period 2000-2005 has been analysed on this study. 


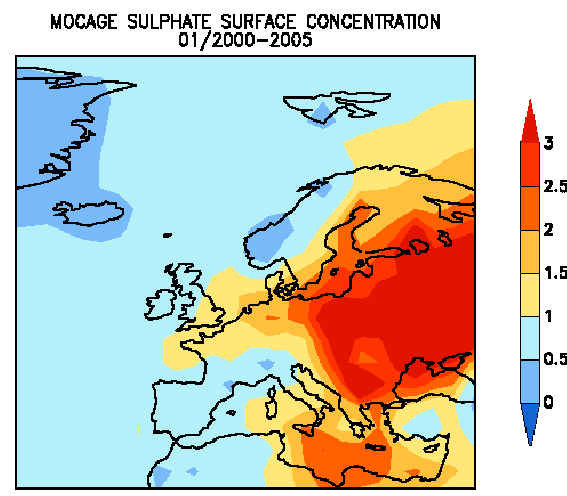

(a)
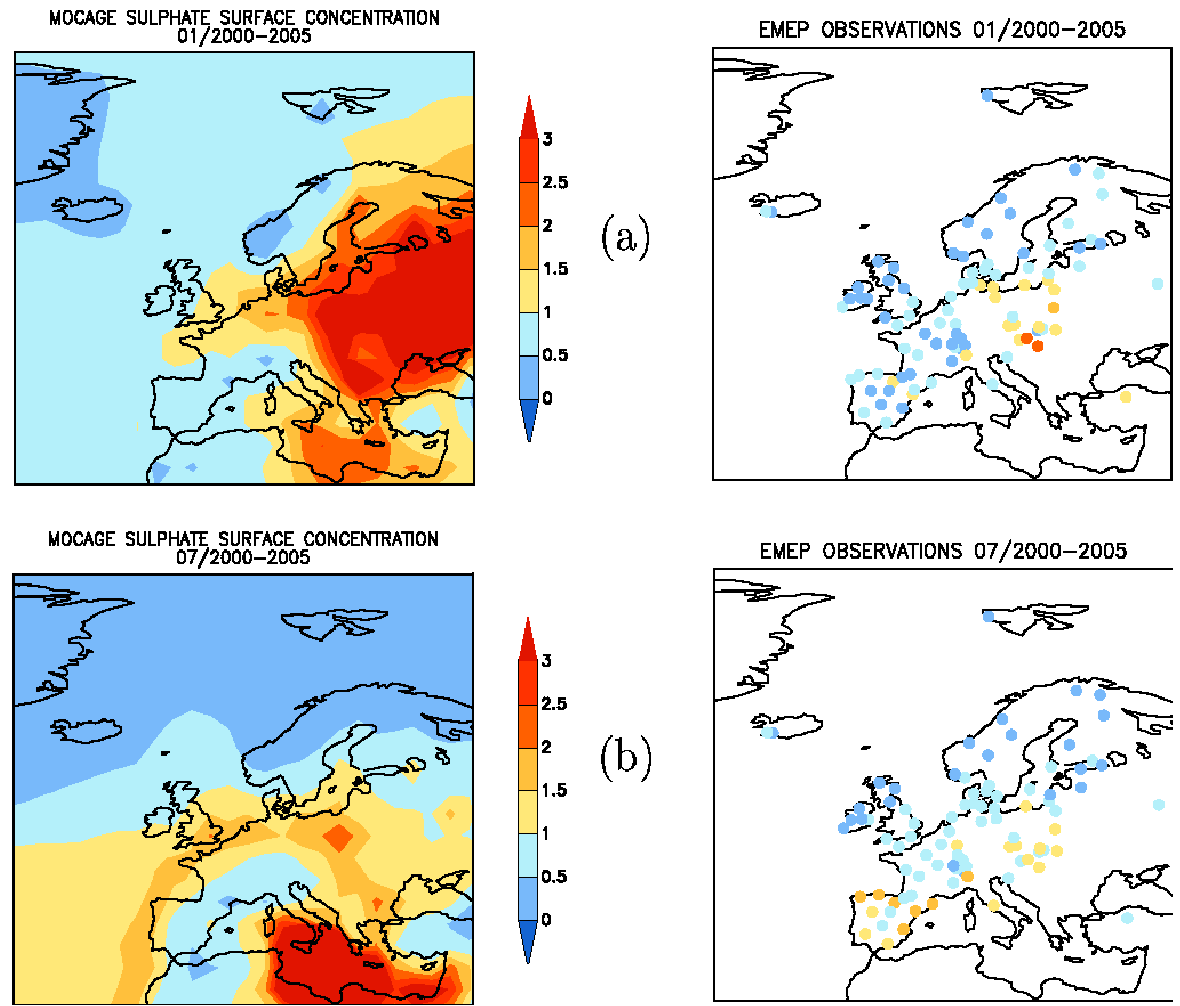

(b)

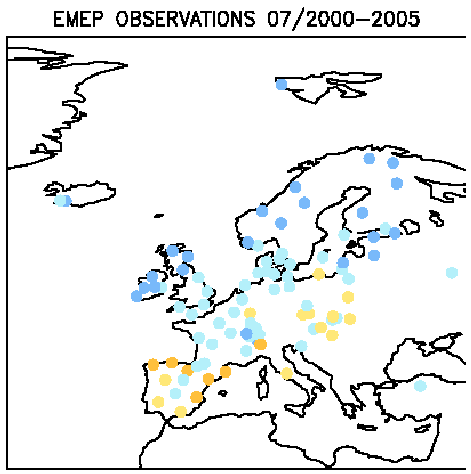

Fig. 11. Sulphate ground concentration modelled by MOCAGE (left) and observed (right), in January (top) and July (bottom). Values $\left(\mu \mathrm{g}[\mathrm{S}] \mathrm{m}^{-3}\right)$ are averaged over 2000-2005.
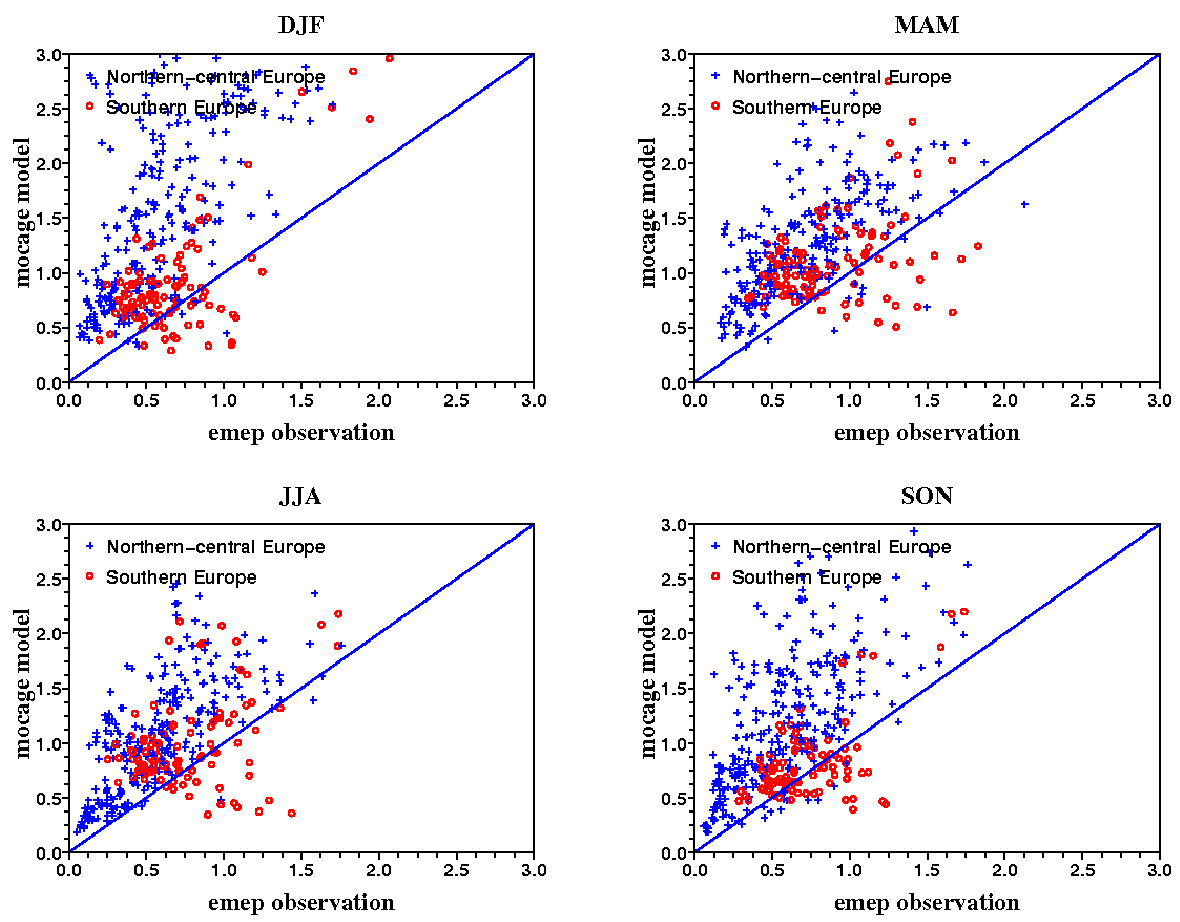

Fig. 12. Seasonal ground concentrations of sulphate $\left(\mu \mathrm{g}[\mathrm{S}] \mathrm{m}^{-3}\right)$ : MOCAGE outputs versus EMEP observations. Three month averages over 2000-2005. 

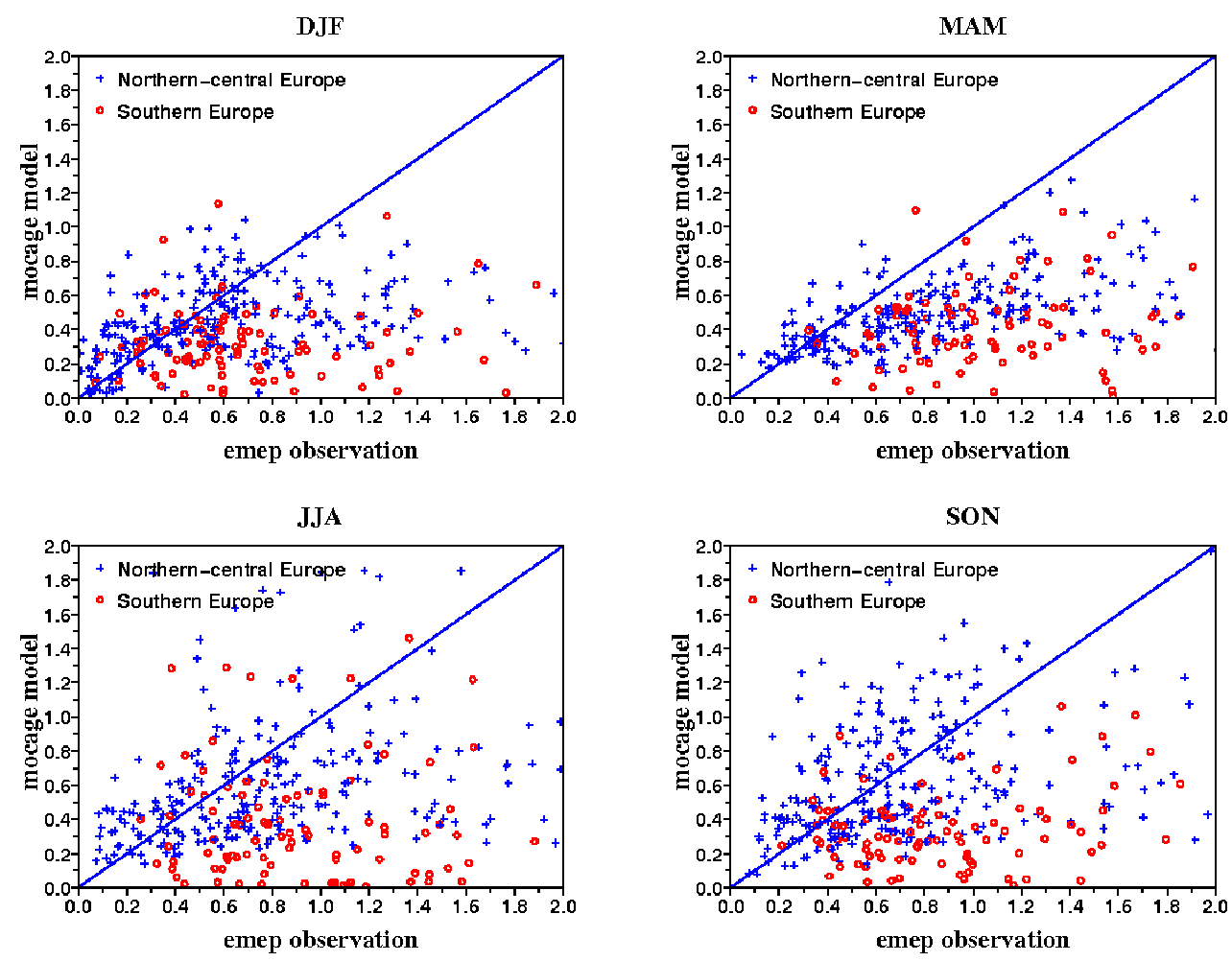

Fig. 13. Seasonal scavenging fluxes of sulphate $\left(\mathrm{g}[\mathrm{S}] \mathrm{m}^{-2} \mathrm{month}^{-1}\right)$ : MOCAGE outputs versus EMEP observations. Three month averages over 2000-2005.
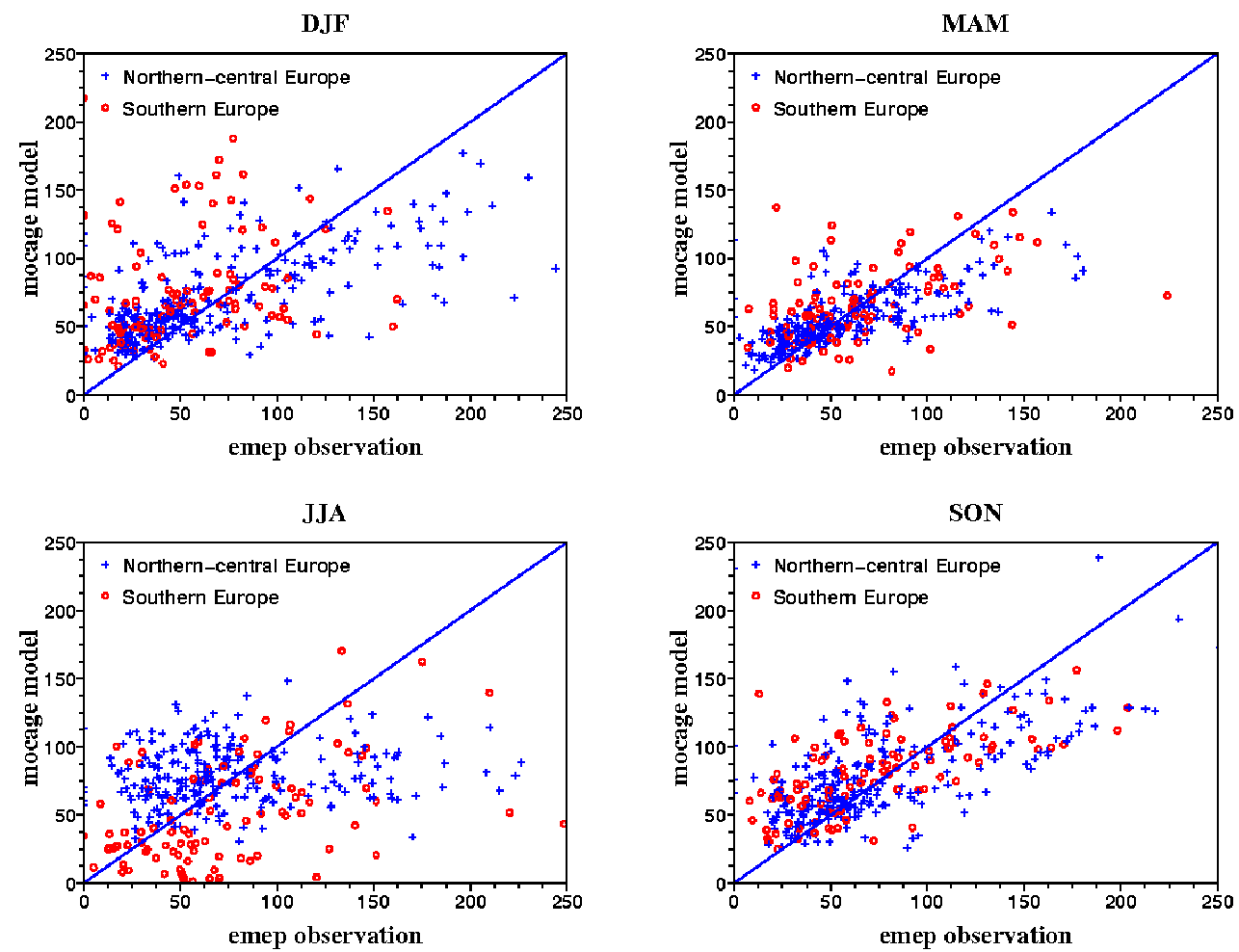

Fig. 14. Seasonal precipitation $\left(\mathrm{mm} \mathrm{month}^{-1}\right)$ : MOCAGE outputs versus EMEP observations. Three month averages over 2000-2005. 
For each year of the simulation, the sulphate burden has a significant annual cycle, with a maximum in May and a minimum in September. Such an annual cycle is caused by the annual cycles of the aqueous and the gaseous chemistry production, combined with spatiotemporal variations of wet deposition: the aqueous chemistry, clearly correlated with precipitation, has a maximum in January and a minimum in July. The gaseous chemistry is correlated with temperatures and shows a maximum in July and a minimum in January. The aqueous chemistry produces three times more sulphate than the gaseous chemistry on average over all our simulation. The aqueous chemistry is very active in winter over Eastern Europe, a region where there are significant anthropogenic emissions. The gaseous chemistry is active in summer over Southern Europe, with dry and warm conditions. Wet deposition, the main sulphate sink, has no clear annual cycle, but is stronger in winter than in summer. In winter, wet deposition has medium values over large parts of the domain considered. In summer, it has low values on most of the domain, except on Eastern Europe, where it has very high values.

Sulphate burden modelled by MOCAGE over Europe were four time higher in average than it is presented on Marmer et al. (2007). More investigations are needed to explain such a difference. From one year to the next, we found sulphate column variations up to $100 \%$. This appears to be linked to the meteorological conditions which drive transport, chemistry and wet deposition. Position of high and lows pressure patterns relative to $\mathrm{SO}_{2}$ emission regions strongly modify the sulphate column. Wind fields strongly affect the sulphate column, evacuating efficiently sulphate aerosols from polluted areas as we showed in the comparison between January 2002 and 2004. The aqueous chemistry is very productive as soon as the atmosphere is humid enough. But with large humidity, the wet deposition moderates significantly the production of the aqueous chemistry.

Sulphate concentrations at the lowest level of the model, averaged over the six years of the simulation for January and July, have been compared to EMEP ground observations. In spite of a general tendency to overestimate sulphate concentrations, the model reproduces them rather accurately in Northern Europe for both months. Over Southern Europe, sulphate concentration are well reproduced in January, but larger discrepancies appear in July. It is unclear whether this comes from an emissions bias or a bad representation of the gaseous chemistry of the model. Considering all seasons, sulphate surface concentrations are often overestimated by the model in Northern Europe, whereas they are more realist in Southern Europe. This is partially due to an underestimation of the scavenging fluxes. The underestimation of precipitation in the model can not explain fully this underestimation of the scavenging fluxes. Further sensibility tests, including testing other scavenging fluxes representations should be performed to evaluate further the factors that drive scavenging of sulphate aerosols.
Acknowledgements. This work formed part of a PhD Thesis at the Centre National de Recherches Météorologiques (CNRM-GAME), Toulouse, funded by Météo-France and the CNRS. The authors wish to thank Anne-G. Hjellbrekke for providing EMEP observations data, Dirk Olivie who gave us computing tools, Aurelien Ribes and Mathieu Joly who helped us to use the SCILAB and GRADS freeware.

Edited by: A. Laaksonen

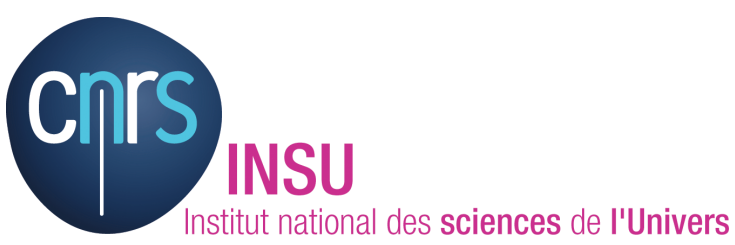

The publication of this article is financed by CNRS-INSU.

\section{References}

Barrie, L. A., Yi, Y., Leaitch, W. R., Lohmann, U., Kasibhatla, P., Roelofs, G.-J., Wilson, J., McGovern, F., Benkovitz, C., Meliere, M. A., Law, K., Prospero, J., Kritz, M., Bergmann, D., Bridgeman, C., Chin, M., Christensen, J., Easter, R., Feichter, J., Land, C., Jeuken, A., Kjellstrom, E., Koch, D., and Rasch, P.: A comparison of large scale atmospheric sulphate aerosol models (COSAM): Overview and highlights, Tellus, 53B, 615-645, doi:10.1034/j.1600-0889.2001.530507.x., 2001.

Bechtold, P., Bazile, E., Guichard, F., Mascart, P., and Richard, E.: A mass flux convection scheme for regional and global models, Q. J. Roy. Meteor. Soc., 127, 869-886, 2001.

Berglen, T. F., Berntsen, T. K., Isaksen, I. S. A., and Sundet, J. K.: A global model of the coupled sulfur/oxidant chemistry in the troposphere: The sulfur cycle, J. Geophys. Res., 109, D19310, doi:10.1029/2003JD003948, 2004

Boucher, O., Pham, M., and Venkataraman, C.: Simulation of the atmospheric sulfur cycle in the Laboratoire de Météorologie Dynamique General Circulation Model, Model Description, Model Evaluation, and Global and European Budgets, Note no. 23, IPSL, 2002.

Charlson, R. J., Schwartz, S. E., Hales, J. M., Cess, R. D., Coakley, J. E., Hansen, J. E., and Hofmann, D. J.: Climate forcing by anthropogenic aerosols, Science, 255, 423-430, 1992.

Crassier, V., Suhre, K., Tulet, P., and Rosset, R.: Development of a reduced chemical scheme for use in mesoscale meteorological models, Atmos. Environ., 34, 2633-2644, 2000.

Delmas, R., Mégie, G., and Peuch, V.-H.: Physique et Chimie de l'Atmosphère, Belin productions, 640 pages, 2005.

Dentener, F., Kinne, S., Bond, T., Boucher, O., Cofala, J., Generoso, S., Ginoux, P., Gong, S., Hoelzemann, J. J., Ito, A., Marelli, L., Penner, J. E., Putaud, J.-P., Textor, C., Schulz, M., van der Werf, G. R., and Wilson, J.: Emissions of primary aerosol and precursor gases in the years 2000 and 1750 prescribed data-sets for AeroCom, Atmos. Chem. Phys., 6, 4321-4344, 2006, http://www.atmos-chem-phys.net/6/4321/2006/.

Hass, H., Van Loon, M., Kessler, C., Stern, R., Matthijsen, J., Sauter, F., Zlatev, Z., Langner, J., Foltescu, V., and Schaap, M.: Aerosol modelling: results and intercomparison from European 
regional scale modeling systems, GLOREAM, EUROTRAC 2 Report, 2003.

Haywood, J. and Boucher, O.: Estimates of the direct and indirect radiative forcing due to tropospheric aerosols: a review, Review of Geophysics, 38, 513-543, 2000.

Hjellbrekke, A.-G.: Data report 2002, acidifying and eutrophying compounds, Tech. Rep. EMEP/CCC Rep. 1/2004, EMEP, Oslo, Norway, 2004.

Intergovernmental Panel on Climate Change, Climate Change: The scientific Basis, Cambridge Univ. Press, Cambridge, UK, 2007.

Josse, B., Simon, P., and Peuch, V.-H.: Rn-222 global simulations with the multiscale CTM MOCAGE, Tellus, 56B, 339-356, 2004

Kasibhatla, P., Chameides, W. L., and John, J. S.: A threedimensional global model investigation of seasonal variations in the atmospheric burden of anthropogenic sulfate aerosols, J. Geophys. Res., 102, 3737-3759, 1997.

Kasper-Gibel, A., Koch, A., Hitzenberger, R. and Puxbaum, H.: Scavenging Efficiency of "Aerosol Carbon" and Sulfate in Supercooled Clouds at Mt. Sonnblick (3106 m a.s.l., Austria), J. Atmos. Chem., 35, 33-46, 2000.

Koch, D., Jacob, D., Tegen, I., Rind, D., and Chin, M.: Tropospheric sulfur simulation and sulfate direct radiative forcing in the Goddard Institute for Space Studies general circulation model, J. Geophys. Res., 104, 23799-23822, doi:10.1029/1999JD900248, 1999.

Langner, J. and Rodhe, H.: A global three-dimensional model of the tropospheric sulphur cycle, J. Atmos. Chem., 13, 225-263, 1991.

Lefèvre, F., Brasseur, G. P., Folkins, I., Smith, A. K., and Simon, P.: Chemistry of the 1991-1992 stratospheric winter : threedimensional simulations, J. Geophys. Res. 99, 8183-8195, 1994.

Lelieveld, J., Crutzen, P. J., and Dentener, F. J.: Changing concentration, lifetime, and climate forcing of atmospheric methane, Tellus, 50B, 128-150, 1998.

Liu, X., Penner, J. E., and Herzog, M.: Global modeling of aerosol dynamics: Model description, evaluation, and interactions between sulfate and nonsulfate aerosols, J. Geophys. Res., 110, D18206, doi:10.1029/2004JD005674, 2005.

Louis, J.-F.: A parametric model of vertical eddy-fluxes in the atmosphere, Bound. Lay. Meteor., 17, 187-202, 1979.

Michou, M. and Peuch, V.-H.: Surface exchanges in the MOCAGE multiscale Chemistry and Transport Model, J. Water Sci., 15, 173-203, 2002.

Marmer, E. and Langmann, B.: Aerosol modeling over Europe: 1. Interannual variability of aerosol distribution, J. Geophys. Res., 112, D23S15, doi:10.1029/2006JD008113, 2007.

Martet, M., Peuch, V.-H., Laurent, B., Marticorena, B., and Marticorena, G.: Evaluation of long-range transport and deposition of desert dust with the CTM MOCAGE, Tellus, 61B, 449-463, 2009.

Nho-Kim, E.-Y., Michou, M., and Peuch, V.-H.: Parameterization of size dependent particle dry deposition velocities for global modeling, Atmos. Environ., 38, 1933-1942, 2004.

Nho, E. Y., Peuch, A., Plu, M., and Peuch, V.-H.: Development of the MOCAGE Atmospheric Chemistry and Transport Model, Rep. Météo-France, 2003.

Pham, M., Müller, J.-F., Brasseur, G. P., Granier, C., and Mégie, G.: A three-dimensionnal study of the tropospheric sulphur cycle, J.
Geophys. Res., 100, 26061-26092, 1995.

Redington, A. L. and Derwent, R. G.: Calculation of sulphate and nitrate aerosol concentrations over Europe using a Lagrangian dispersion model, Atmos. Environ, 36, 4425-4439, 2002.

Seinfeld, J. H. and Pandis, S. N.: Atmospheric Chemistry and Physics: From Air Pollution to Climate Change, second edition, 1203 pp., John Wiley, New York, 2006.

Schaap, M., van Loon, M., ten Brink, H. M., Dentener, F. J., and Builtjes, P. J. H.: Secondary inorganic aerosol simulations for Europe with special attention to nitrate, Atmos. Chem. Phys., 4, 857-874, 2004, http://www.atmos-chem-phys.net/4/857/2004/.

Stohl, A.: Characteristics of atmospheric transport into the Arctic troposphere, J. Geophys. Res., 111, D11306, doi:10.1029/2005JD006888, 2006.

Textor, C., Schulz, M., Guibert, S., Kinne, S., Balkanski, Y., Bauer, S., Berntsen, T., Berglen, T., Boucher, O., Chin, M., Dentener, F., Diehl, T., Feichter, J., Fillmore, D., Ginoux, P., Gong, S., Grini, A., Hendricks, J., Horowitz, L., Huang, P., Isaksen, I. S. A., Iversen, T., Kloster, S., Koch, D., Kirkevåg, A., Kristjansson, J. E., Krol, M., Lauer, A., Lamarque, J. F., Liu, X., Montanaro, V., Myhre, G., Penner, J. E., Pitari, G., Reddy, M. S., Seland, Ø., Stier, P., Takemura, T., and Tie, X.: The effect of harmonized emissions on aerosol properties in global models - an AeroCom experiment, Atmos. Chem. Phys., 7, 4489-4501, 2007, http://www.atmos-chem-phys.net/7/4489/2007/.

Textor, C., Schulz, M., Guibert, S., Kinne, S., Balkanski, Y., Bauer, S., Berntsen, T., Berglen, T., Boucher, O., Chin, M., Dentener, F., Diehl, T., Easter, R., Feichter, H., Fillmore, D., Ghan, S., Ginoux, P., Gong, S., Grini, A., Hendricks, J., Horowitz, L., Huang, P., Isaksen, I., Iversen, I., Kloster, S., Koch, D., Kirkevåg, A., Kristjansson, J. E., Krol, M., Lauer, A., Lamarque, J. F., Liu, X., Montanaro, V., Myhre, G., Penner, J., Pitari, G., Reddy, S., Seland, Ø., Stier, P., Takemura, T., and Tie, X.: Analysis and quantification of the diversities of aerosol life cycles within AeroCom, Atmos. Chem. Phys., 6, 1777-1813, 2006, http://www.atmos-chem-phys.net/6/1777/2006/.

Teyssèdre, H., Michou, M., Clark, H. L., Josse, B., Karcher, F., Olivié, D., Peuch, V.-H., Saint-Martin, D., Cariolle, D., Attié, J.-L., Nédélec, P., Ricaud, P., Thouret, V., van der A, R. J., VolzThomas, A., and Chéroux, F.: A new tropospheric and stratospheric Chemistry and Transport Model MOCAGE-Climat for multi-year studies: evaluation of the present-day climatology and sensitivity to surface processes, Atmos. Chem. Phys., 7, 58155860, 2007, http://www.atmos-chem-phys.net/7/5815/2007/.

Trivitayanurak, W., Adams, P. J., Spracklen, D. V., and Carslaw, K. S.: Tropospheric aerosol microphysics simulation with assimilated meteorology: model description and intermodel comparison, Atmos. Chem. Phys., 8, 3149-3168, 2008, http://www.atmos-chem-phys.net/8/3149/2008/.

Twomey, S.: The influence of pollution on the short wave albedo of clouds, J. atmosph. Sci., 34, 1149-1152, 1977.

Wesely, M. L.: Parameterization of surface resistances to gaseous dry deposition in regional-scale numerical models, Atmos. Environ., 23, 1293-1304, 1989.

Williamson, D. L. and Rash, P. J.: Two-dimensional semilagrangian transport with shape-preserving interpolation, Mon Weather Rev., 117, 102-129, 1989.

World Health Organization, World health report 2002, technical report, Geneva, Switzerland, 2002. 